\title{
Erratum to: In vitro activities of plant extracts from the Brazilian Cerrado and Pantanal against Rhipicephalus (Boophilus) microplus (Acari: Ixodidae)
}

\section{Carolina da Silva Barbosa • Ligia Miranda Ferreira Borges • José Nicácio • Reginaldo Dias Alves • Carlos Henrique Miguita • Ivana Maria Póvoa Violante • Lidilhone Hamerski • Walmir Silva Garcez • Fernanda Rodrigues Garcez}

Published online: 24 April 2013

(C) Springer Science+Business Media Dordrecht 2013

\section{Erratum to: Exp Appl Acarol DOI 10.1007/s10493-013-9656-z}

Due to an unfortunate turn of events, a typographical error was introduced in the Abstract of the original publication. The percentage of product effectiveness of the extract from the trunk of Strychnos pseudoquina (Loganiaceae) was incorrectly displayed as $8.0 \%$.

The correct value is $48 \%$ and should be treated as definitive by the reader.

The online version of the original article can be found under doi:10.1007/s10493-013-9656-z.

C. da S. Barbosa $(\bowtie) \cdot$ R. D. Alves

Laboratório de Parasitologia Animal, Universidade Estadual de Mato Grosso do Sul,

Unidade de Aquidauana, Aquidauana, MS 79200-000, Brazil

e-mail: csmangarosa@gmail.com

L. M. F. Borges

Setor de Parasitologia, Instituto de Patologia Tropical e Saúde Pública,

Universidade Federal de Goiás, Goiânia, GO, Brazil

J. Nicácio

Laboratório de Entomologia, Universidade Federal da Grande Dourados, Dourados, MS, Brazil

C. H. Miguita · I. M. P. Violante - L. Hamerski · W. S. Garcez · F. R. Garcez

Centro de Ciências Exatas e Tecnologia, Universidade Federal de Mato Grosso do Sul, Campo Grande, MS, Brazil 